\title{
Soluble receptor for advanced glycation end products in COPD: relationship with emphysema and chronic cor pulmonale: a case-control study
}

Massimo Miniati ${ }^{1 *}$, Simonetta Monti ${ }^{2,3}$, Giuseppina Basta ${ }^{2,3}$, Franca Cocci ${ }^{2,3}$, Edo Fornai ${ }^{2,3}$ and Matteo Bottai ${ }^{4,5}$

\begin{abstract}
Background: The receptor for advanced glycation end products (RAGE) is a multiligand signal transduction receptor that can initiate and perpetuate inflammation. Its soluble isoform (sRAGE) acts as a decoy receptor for RAGE ligands, and is thought to afford protection against inflammation. With the present study, we aimed at determining whether circulating SRAGE is correlated with emphysema and chronic cor pulmonale in chronic obstructive pulmonary disease (COPD).

Methods: In 200 COPD patients and 201 age- and sex-matched controls, we measured lung function by spirometry, and sRAGE by ELISA method. We also measured the plasma levels of two RAGE ligands, N-epsiloncarboxymethyl lysine and S100A12, by ELISA method. In the COPD patients, we assessed the prevalence and severity of emphysema by computed tomography $(C T)$, and the prevalence of chronic cor pulmonale by echocardiography. Multiple quantile regression was used to assess the effects of emphysema, chronic cor pulmonale, smoking history, and comorbid conditions on the three quartiles of sRAGE.

Results: sRAGE was significantly lower ( $p=0.007$ ) in COPD patients (median $652 \mathrm{pg} / \mathrm{mL}$, interquartile range 484 to $1076 \mathrm{pg} / \mathrm{mL}$ ) than in controls (median $869 \mathrm{pg} / \mathrm{mL}$, interquartile range 601 to $1240 \mathrm{pg} / \mathrm{mL}$ ), and was correlated with the severity of emphysema $(p<0.001)$, the lower the level of sRAGE the greater the degree of emphysema on $C T$. The relationship remained statistically significant after adjusting for smoking history and comorbid conditions. In addition, sRAGE was significantly lower in COPD patients with chronic cor pulmonale than in those without $(p=$ 0.002). Such difference remained statistically significant after adjusting for smoking history, comorbidities, and emphysema severity. There was no significant difference in the plasma levels of the two RAGE ligands between cases and controls.

Conclusions: SRAGE is significantly lower in patients with COPD than in age- and sex-matched individuals without airflow obstruction. Emphysema and chronic cor pulmonale are independent predictors of reduced sRAGE in COPD.
\end{abstract}

\section{Background}

Chronic obstructive pulmonary disease (COPD) is a major cause of morbidity, disability, and mortality in industrialized countries [1]. It is characterized by an inflammatory response of the lung to inhaled noxious agents which brings about progressive airflow obstruction [1]. COPD also features a systemic inflammatory component with muscle wasting and weight loss $[2,3]$.

\footnotetext{
* Correspondence: massimo.miniati@unifi.it

'Department of Medical and Surgical Critical Care, University of Florence, 50134 Florence, Italy

Full list of author information is available at the end of the article
}

The forced expiratory volume in one second $\left(\mathrm{FEV}_{1}\right)$ is used in clinical practice for the diagnosis and staging of COPD, but it is deemed insufficient for the full characterization of patients with established COPD [4]. A large-scale prospective study is now underway to define clinically relevant COPD phenotypes, and identify biomarkers, correlated with such phenotypes, that might predict the disease progression and the effect of therapeutic interventions $[5,6]$.

The receptor for advanced glycation end products (RAGE) is a $35 \mathrm{kD}$ transmembrane receptor belonging to the immunoglobulin superfamily [7]. RAGE interacts 
with a variety of ligands including amyloid peptide, $\mathrm{N}$-epsilon-carboxymethyl lysine (CML), S100 proteins, and the DNA-binding protein "high mobility group box 1" (HMGB1) [8]. Binding of RAGE with its ligands is thought to trigger a pro-inflammatory gene activation [9].

Soluble RAGE (sRAGE), an isoform of RAGE lacking transmembrane and cytosolic domains, acts as a decoy receptor for RAGE ligands in the extracellular compartment, and is believed to afford protection against inflammation and cell injury [10]. Reportedly, sRAGE levels are reduced in patients with coronary artery disease, rheumatoid arthritis, and idiopathic pulmonary fibrosis as compared with healthy subjects [11-14].

In a study comprising 61 patients with COPD and 42 healthy controls, Smith and coworkers showed that sRAGE is significantly correlated with $\mathrm{FEV}_{1}$ as percent predicted, the greater the degree of airflow obstruction the lower the plasma concentration of sRAGE [15].

Recently, Ferhani et al. [16] reported that RAGE is over-expressed in the airway epithelium and in the airway smooth muscle of smokers with COPD, and colocalizes with HMGB1. In that study, the circulating levels of sRAGE were not measured.

With the present study, we aimed at establishing whether plasma levels of sRAGE and of its ligands CML and S100A12 are correlated with the presence and severity of emphysema in a sample of 200 patients with COPD who were recruited into a multicenter European study on genetic susceptibility to the development of COPD. An equal sample of subjects without airflow obstruction served as controls.

As a secondary end-point, we looked for an association between sRAGE and chronic cor pulmonale in COPD.

\section{Methods \\ Sample}

The study sample included 200 patients with COPD and 201 controls who were part of a larger cohort enrolled in a case-control study aimed at assessing genetic susceptibility to the development of COPD [17-20].

The subjects, all white Caucasian, were evaluated at the outpatient clinic of the CNR Institute of Clinical Physiology, Pisa, Italy, between November 1, 2001 and September 30, 2003. Potential candidates were contacted through the family physicians in the city of Pisa.

Criteria for case recruitment were: (a) firm clinical diagnosis of stable COPD, (b) airflow obstruction as indicated by a post-bronchodilator ratio of forced expiratory volume in one second over forced vital capacity $\left(\mathrm{FEV}_{1} / \mathrm{FVC}\right)<0.7$ and $\mathrm{FEV}_{1} \leq 70 \%$ of the predicted value [21], and (c) smoking history $\geq 20$ pack-years.
Patients were excluded from the study if they had an established diagnosis of asthma, chronic lung disorders other than COPD or lung cancer, history of atopy, known alpha-1-antitrypsin deficiency, or a serum alpha1 -antitrypsin concentration $<1.0 \mathrm{~g} / \mathrm{dL}$. Patients were also excluded if they had had a clinically confirmed acute exacerbation in the 4 weeks preceding the study entry.

By study design, the controls were recruited to match the COPD patients on age and gender. All the controls were current or former smokers with a smoking history $\geq 20$ pack-years. Only individuals with no airflow obstruction were included in the control group $\left(\mathrm{FEV}_{1} /\right.$ FVC $>0.7$; FVC and $\mathrm{FEV}_{1}>80 \%$ of the predicted value). Individuals were excluded from the control group if they had a history of chronic lung disease or atopy, a family history of COPD, or had had an acute respiratory infection in the 4 weeks preceding the study entry.

\section{Study protocol}

The protocol was approved by the local ethics committee (Comitato Etico, Azienda Ospedaliero-Universitaria Pisana, Pisa, Italy). Before entering the study, an informed written consent was obtained from all the subjects.

Detailed clinical history and physical examination were obtained in each participant. Definitions of comorbid conditions are reported in the online additional file. Lung function studies included the measurement of FVC and $\mathrm{FEV}_{1}$ (before and after bronchodilator), and of single breath diffusing capacity of the lung for carbon monoxide $\left(\mathrm{DL}_{\mathrm{CO}}\right)$. Spirometry, and $\mathrm{DL}_{\mathrm{CO}}$ measurements were performed in conformity with the ATS/ERS standards $[22,23]$. The severity of COPD was staged according to the GOLD guidelines [1].

Chronic cor pulmonale was rated present if there was evidence of persistent enlargement of the right ventricle on at least two consecutive echocardiographic studies obtained in the year preceding the study entry. Diagnostic criteria included an end-diastolic right ventricular diameter $>26 \mathrm{~mm}$ in the parasternal long-axis view, or a ratio of right-to-left end-diastolic ventricular diameter $>1$ in the apical four-chamber view [24]. Right ventricle hypertrophy was rated present if the thickness of the right ventricular free wall was $\geq 7 \mathrm{~mm}$ in the subcostal view [24].

Postero-anterior and lateral digital chest radiographs were obtained in all the subjects at the time of enrollment in the study, and were examined by two chest physicians for the presence of heart and pulmonary abnormalities. The COPD patients were also invited to complete a self-administered quality-of-life questionnaire [25]. Upon inclusion, a blood sample (in lithium heparin) was obtained from all the subjects for genomic 
studies. Plasma aliquots were stored at $-80^{\circ} \mathrm{C}$ until futher processing.

\section{Measurement of sRAGE}

The plasma concentration of sRAGE was determined using a double-sandwich ELISA method (DuoSet ELISA kit, R\&D Systems, Minneapolis, MN). The methodology is described in full elsewhere [26], and is reported briefly in the online additional file. With this assay, the lower limit of detection of sRAGE is $21.5 \mathrm{pg} / \mathrm{mL}$ [26]. Our ELISA method measures total sRAGE because it utilizes an antibody directed against the extracellular domain, so it cannot distinguish the shedded isoform from the splice variant of RAGE (also known as endogenous secretory RAGE, or esRAGE).

We also measured the plasma concentrations of two RAGE ligands, CML and S100A12, by ELISA method (see online additional file). CML can be generated on proteins by a myeloperoxidase-dependent pathway when neutrophils are activated [27]. Similarly, S100A12 is secreted by cytokine-activated neutrophils [28]. Since COPD is characterized by neutrophil activation, we thought it appropriate to measure the circulating levels of the two ligands in our study sample.

\section{Computed tomography}

Computed tomography (CT) of the thorax was obtained in COPD patients within three months of their recruitment into the study. It was performed on a Toshiba Aquilion 64 detector row scanner (Toshiba, Japan) with the patient breath-holding at full inspiration for 10 seconds. Acquisition setting was $120 \mathrm{kVp}$ with mAs modulated according to the patient's attenuation as assessed before scan acquisition (range, 60 to $250 \mathrm{mAs}$ ). Slice thickness was set at $0.65 \mathrm{~mm}$. No contrast medium was infused. Scans were reconstructed in the axial, sagittal and coronal planes. Images were viewed using a window level of -600 Hounsfield Units (HU) and a width of $1,500 \mathrm{HU}$, and were examined independently by a chest radiologist and a chest physician for the presence of areas of low attenuation and vascular disruption. The two raters were blinded to clinical and lung function data.

Maximum intensity projection technique was used to evaluate vascular disruption, and minimum intensity projection to highlight focal areas of low attenuation in the lung parenchyma [29].

The severity of emphysema was scored on a nonparametric scale from 0 (no emphysema) to 100 using the panel-grading (PG) method of Thurlbeck et al. [30]. This consists of 16 inflation-fixed, paper-mounted, midsagittal whole lung sections that are arranged at intervals of 5 between 0 and 50 , and at intervals of 10 between 60 and 100. A score of 5 or less is consistent with trace emphysema, a score of 10 to 30 indicates mild emphysema, a score $>30$ to 50 moderate emphysema, and a score $>50$ to 100 severe emphysema [30]. In scoring emphysema on $\mathrm{CT}$, the two raters examined sagittal lung sections, and gave them the score of the standard most closely similar, or a score between two standards. Examples are shown in the online additional file. The PG scores by the two independent raters were averaged.

\section{Statistical analysis}

Differences between and within groups were assessed by Fisher's exact test for the categorical variables, and by Mood's median test for the continuous variables. Continuous variables in the text and in the tables are reported as median and interquartile range (IQR). The scatter plot of the PG of emphysema by the two independent raters was tested for departure from perfect agreement by fitting a simple linear regression model and testing the null hypothesis that the intercept is equal to zero and the slope is equal to one, jointly.

We utilized the data from the 200 COPD patients and the 201 age and sex-matched controls to estimate the effects on the three quartiles $\left(25^{\text {th }}, 50^{\text {th }}\right.$, and $75^{\text {th }}$ percentile) of sRAGE of the following variables: pack-years of smoking, coronary artery disease, diabetes mellitus, dyslipidemia, airflow obstruction as reflected by $\mathrm{FEV}_{1} \%$ predicted, and emphysema on CT. Airflow obstruction was dichotomized as absent $\left(\mathrm{FEV}_{1}>80 \%\right)$ or present $\left(\mathrm{FEV}_{1}<80 \%\right)$. Emphysema was categorized as absent, mild, moderate, or severe based on the PG score. "Absent" emphysema with no airflow obstruction was the reference category. We tested for trends across the varying degrees of severity of emphysema. We included chronic cor pulmonale in a secondary analysis. Sex and age were matching variables by design, and their effect could not be assessed. The potential dependence of the observations within each matched group was taken into account by using cluster bootstrap for the inference on the three quartiles of sRAGE. The statistical analysis was performed with Stata version 10 (StataCorp, College Station, TX).

\section{Results}

\section{Sample characteristics}

The baseline characteristics of the study sample are summarized in table 1 . The control subjects were matched to the COPD patients on age and gender, and did not differ from them with regard to body mass index (BMI). The proportion of current smokers was nearly identical in the two groups, but the cumulative exposure to cigarette smoking was significantly higher in COPD than in controls. The two groups had a similar prevalence of comorbid conditions. 
Table 1 Baseline characteristics of the study sample

\begin{tabular}{lccc}
\hline Characteristics & $\begin{array}{c}\text { COPD } \\
(\mathbf{n}=\mathbf{2 0 0})\end{array}$ & $\begin{array}{c}\text { No COPD } \\
(\mathbf{n}=\mathbf{2 0 1})\end{array}$ & P-value \\
\hline Age, years & $66(61-70)$ & $65(61-70)$ & 0.258 \\
Male sex & $178(89)$ & $172(86)$ & 0.369 \\
BMI $\left(\mathrm{kg} / \mathrm{m}^{2}\right)$ & $27(24-31)$ & $28(25-30)$ & 0.508 \\
Current smoker & $97(49)$ & $101(50)$ & 0.766 \\
Pack-years of smoking & $48(39-60)$ & $40(33-50)$ & $<0.001$ \\
FEV $_{1}, \%$ predicted & $54(42-65)$ & $95(88-105)$ & $<0.001$ \\
DLCo, \% predicted $_{\text {Chronic mucous hypersecretion }}$ & $76(58-86)$ & $96(86-108)$ & $<0.001$ \\
Chronic cor pulmonale & $116(58)$ & $46(23)$ & $<0.001$ \\
Emphysema & $47(24)$ & $0(0)$ & $<0.001$ \\
& $87(44)$ & $0(0)$ & $<0.001$
\end{tabular}

Comorbidity

Systemic arterial hypertension

Coronary artery disease

Heart failure

Dilated cardiomyopathy

Left heart valvular disease

Chronic atrial fibrillation

Prior stroke

Prior PE or DVT

Renal failure

Diabetes mellitus

Dyslipidemia

Thyroid dysfunction

Chronic hepatitis C

Therapy

Inhaled bronchodilators

Inhaled corticosteroids

Oral theophylline

Long-term oxygen

Cardiovascular drugs

Diuretics

Warfarin

Statins

Oral hypoglicemic drugs/insulin

Thyroid replacement therapy

Data are reported as median (interquartile range), or number (\%). Definitions of abbreviations: $\mathrm{BMI}=$ body mass index; $\mathrm{FEV}_{1}=$ forced expiratory volume in one second; $\mathrm{DL}_{\mathrm{CO}}=$ diffusing capacity of the lung for carbon monoxide; $\mathrm{PE}=$ pulmonary embolism; $\mathrm{DVT}=$ deep vein thrombosis.

Emphysema was consistently diagnosed by the two independent raters in $87(44 \%)$ of 200 patients with COPD (see online additional file for inter-rater agreement). In the 87 emphysemic patients, the median PG score was 46 (IQR, 39 to 59). In the whole COPD sample, the PG score of emphysema was significantly correlated with $\mathrm{FEV}_{1}$ as \% predicted $(\mathrm{r}=-0.62, \mathrm{p}<0.001)$, and with $\mathrm{DL}_{\mathrm{CO}}$ as \% predicted $(\mathrm{r}=-0.67, \mathrm{p}<0.001)$.

Based on the PG score, the COPD sample was divided in three categories: no or mild emphysema ( $P G \leq 30$, $\mathrm{n}=119$ ), moderate emphysema ( $\mathrm{PG}>30$ to $50, \mathrm{n}=56$ ), and severe emphysema ( $\mathrm{PG}>50, \mathrm{n}=25)$.

As shown in table 2, the COPD patients with moderate to severe emphysema ( $\mathrm{PG}>30$ ) had significantly lower $\mathrm{BMI}, \mathrm{FEV}_{1}$ and $\mathrm{DL}_{\mathrm{CO}}$, and featured a significantly higher prevalence of chronic cor pulmonale and a worse quality of life than those with no or mild emphysema $(\mathrm{PG} \leq 30)$.

Systemic arterial hypertension and dyslipidemia prevailed significantly in the patients with $P G \leq 30$ with respect to those having $\mathrm{PG}>30$ (table 2). In the latter group, significantly more patients were receiving inhaled bronchodilators and oral theophylline than those with PG $\leq 30$ (table 2).

\section{Circulating levels of sRAGE}

The median circulating level of sRAGE in COPD patients was $652 \mathrm{pg} / \mathrm{mL}$ (IQR, 484 to $1076 \mathrm{pg} / \mathrm{mL}$ ), and was significantly lower $(\mathrm{p}=0.007)$ than in controls (median $869 \mathrm{pg} / \mathrm{mL}$, IQR 601 to $1240 \mathrm{pg} / \mathrm{mL}$ ).

Among the COPD patients, there was no significant difference in the levels of sRAGE between current and former smokers, nor there was any difference in relation to the cumulative smoking history (table 3 ).

With regard to lung function, there was a significant relationship between sRAGE and the degree of airflow obstruction, the lower the level of sRAGE the greater the airflow obstruction (table 3). Similarly, sRAGE was significantly lower in the COPD patients with $\mathrm{DL}_{\mathrm{CO}}$ below the median value than in those with $\mathrm{DL}_{\mathrm{CO}}$ above the median, so indicating a relationship with functional emphysema (table 3).

A significant difference was confirmed when the comparison was made with the severity of structural emphysema on CT, sRAGE being the lowest in the patients with severe emphysema (table 3 , figure 1 ). Also, sRAGE was significantly lower in the COPD patients with chronic cor pulmonale than in those without (table 3).

Diabetes was associated with significantly higher values of sRAGE, whereas cardiovascular disorders, dyslipidemia, and use of inhaled corticosteroids or statins had no effect on the plasma concentration of sRAGE (table 3).

Among the controls, there was no significant difference in the circulating levels of sRAGE in relation to smoking habits, relevant comorbidities, or statin use (table 4).

Figure 2 shows the differences in median sRAGE between the COPD patients, categorized as a function of emphysema severity, and the controls taken as the reference category. The difference in median sRAGE increased with increasing emphysema severity, and was statistically significant at all levels of severity with respect to the reference category. The observed differences remained statistically significant even after adjusting for other independent variables such as airflow obstruction, pack-years 
Table 2 Baseline characteristics of COPD patients in relation to the presence and severity of emphysema

\begin{tabular}{|c|c|c|c|}
\hline Characteristics & $\begin{array}{c}\text { No or mild } \\
(n=119)\end{array}$ & $\begin{array}{c}\text { Moderate } \\
\text { to severe } \\
(\mathrm{n}=81)\end{array}$ & P-value \\
\hline Age, years & $66(60-69)$ & $67(62-71)$ & 0.475 \\
\hline Male sex & $105(88)$ & $73(90)$ & 0.819 \\
\hline $\mathrm{BMI}\left(\mathrm{kg} / \mathrm{m}^{2}\right)$ & $29(26-31)$ & $25(23-27)$ & $<0.001$ \\
\hline Current smoker & $60(50)$ & $37(46)$ & 0.565 \\
\hline Pack-years of smoking & $46(38-59)$ & $50(40-60)$ & 0.152 \\
\hline $\mathrm{FEV}_{1}, \%$ predicted & $60(51-66)$ & $42(32-53)$ & $<0.001$ \\
\hline $\mathrm{DL}_{\mathrm{co}}, \%$ predicted & $83(74-97)$ & $57(47-71)$ & $<0.001$ \\
\hline Chronic mucous hypersecretion & $65(55)$ & $51(63)$ & 0.248 \\
\hline Chronic cor pulmonale & $16(13)$ & $31(38)$ & $<0.001$ \\
\hline QoL questionnaire, total score & $28(19-41)$ & $40(21-60)$ & 0.009 \\
\hline \multicolumn{4}{|l|}{ Comorbidity } \\
\hline Systemic arterial hypertension & $67(56)$ & $28(35)$ & 0.004 \\
\hline Coronary artery disease & $37(31)$ & $22(27)$ & 0.636 \\
\hline Heart failure & $12(10)$ & $11(14)$ & 0.502 \\
\hline Diabetes mellitus & $15(13)$ & $7(9)$ & 0.492 \\
\hline Dyslipidemia & $44(37)$ & $17(21)$ & 0.019 \\
\hline \multicolumn{4}{|l|}{ Therapy } \\
\hline Inhaled bronchodilators & $74(62)$ & $65(80)$ & 0.008 \\
\hline Inhaled corticosteroids & $71(60)$ & $57(70)$ & 0.135 \\
\hline Oral theophylline & $22(18)$ & $26(32)$ & 0.030 \\
\hline Cardiovascular drugs & $80(67)$ & $42(52)$ & 0.039 \\
\hline Diuretics & $28(24)$ & $24(30)$ & 0.412 \\
\hline Statins & $25(21)$ & $12(15)$ & 0.354 \\
\hline
\end{tabular}

Data are reported as median (interquartile range), or number (\%). Definitions of abbreviations: $\mathrm{QoL}=$ quality of life.

For the other abbreviations see table 1.

of smoking, coronary artery disease, diabetes, and dyslipidemia.

The unadjusted difference in median sRAGE between the COPD patients with and those without chronic cor pulmonale was $-181 \mathrm{pg} / \mathrm{mL}$ (table 3). After adjusting for smoking history, comorbid conditions, and emphysema severity, the difference in median sRAGE between the two groups decreased to $-168 \mathrm{pg} / \mathrm{mL}$, but remained statistically significant $(\mathrm{p}<0.001)$.

The interaction between emphysema and chronic cor pulmonale was not statistically significant. This means that both variables are important predictors of reduced sRAGE, but the effect of either variable does not vary in relation to the presence or absence of the other.

\section{Circulating levels of $\mathrm{N}$-epsilon-carboxymethyl lysine and S100A 12}

The median circulating level of CML in COPD patients was $53 \mathrm{mcg} / \mathrm{mL}$ (IQR, 35 to $72 \mathrm{mcg} / \mathrm{mL}$ ), and did not differ $(\mathrm{p}=0.42)$ from that of controls (median $50 \mathrm{mcg} / \mathrm{mL}$,
IQR 35 to $72 \mathrm{mcg} / \mathrm{mL}$ ). Similarly, we found no difference in the plasma concentration of S100A12 between cases and controls, the median value of S100A12 being $42 \mathrm{ng} / \mathrm{mL}$ (IQR, 30 to $61 \mathrm{ng} / \mathrm{mL}$ ) in the COPD patients, and $42 \mathrm{ng} / \mathrm{mL}$ (IQR, 33 to $57 \mathrm{ng} / \mathrm{mL}$ ) in the controls $(\mathrm{p}=0.71)$.

Among the patients with COPD, there was no significant correlation between sRAGE and CML $(r=-0.062$, $\mathrm{p}=0.38)$, or S100A12 levels $(\mathrm{r}=-0.048, \mathrm{p}=0.50)$. Lack of correlation between sRAGE and the two RAGE ligands was confirmed in the controls $(\mathrm{r}=0.007, \mathrm{p}=$ 0.92 vs $C M L ; r=0.013, p=0.86$ vs S100A12).

\section{Discussion}

Over recent years, a number of reports showed that, relative to healthy controls, sRAGE is significantly reduced in a variety of disorders including coronary artery disease, rheumatoid arthritis, and idiopathic pulmonary fibrosis [11-14]. Since sRAGE acts as a decoy receptor for RAGE ligands, reduced levels of sRAGE are thought to be expression of an impaired immunologic control [11-14].

In the study by Smith and coworkers, circulating sRAGE was significantly correlated with $\mathrm{FEV}_{1}$ as percent predicted, the greater the degree of airflow obstruction the lower the plasma concentration of sRAGE [15]. In a subset of 36 COPD patients, no significant relationship was observed between the plasma concentration of sRAGE and the lung diffusing capacity as reflected by $\mathrm{DL}_{\mathrm{CO}}$ [15]. In that study, radiologic imaging of the chest was not available, so the relationship between sRAGE and emphysema could not be assessed.

In the present study, we found that circulating sRAGE is significantly lower in patients with stable COPD than in subjects without airflow obstruction who are matched to COPD patients on age and gender, and who also feature very similar comorbid conditions.

The reduction of sRAGE in COPD was strongly associated with the impairment of lung diffusing capacity, and the severity of structural emphysema as seen on CT. The association of sRAGE with emphysema remained statistically significant after adjusting for a number of independent variables including cumulative smoking history, coexistence of coronary artery disease, diabetes mellitus, or dyslipidemia.

In our sample, there were no cases of interstitial lung diseases since, by design, all the patients with chronic lung disorders other than COPD were excluded from the study.

One subject only was affected by rheumatoid arthritis - a 64-year old male who had normal lung function $\left(\mathrm{FEV}_{1} / \mathrm{FVC}>0.7, \mathrm{FEV}_{1} 92 \%\right.$ predicted, and $\mathrm{DL}_{\mathrm{CO}} 100 \%$ predicted), and no abnormality on chest radiography. In this subject, the plasma concentration of sRAGE was $292 \mathrm{pg} / \mathrm{mL}$. 
Table 3 sRAGE in 200 COPD patients (univariate analysis)

\begin{tabular}{|c|c|c|c|c|}
\hline Characteristics & $\mathrm{n}$ & Median & IQR & P-value \\
\hline \multicolumn{5}{|l|}{ Smoking habits } \\
\hline Current smoker & 97 & 677 & 483-1076 & 0.777 \\
\hline Former smoker & 103 & 638 & $492-1063$ & \\
\hline \multicolumn{5}{|l|}{ Pack-years of smoking } \\
\hline$>48$ & 96 & 628 & 449-1055 & 0.479 \\
\hline$\leq 48$ & 104 & 669 & 484-1076 & \\
\hline \multicolumn{5}{|l|}{$F E V_{1}, \%$ predicted } \\
\hline$\geq 50$ & 122 & 660 & 503-1078 & 0.015 \\
\hline$<50$ & 62 & 763 & $538-1138$ & \\
\hline$<30$ & 16 & 435 & $247-544$ & \\
\hline \multicolumn{5}{|l|}{ DL $L_{\mathrm{CO}} \%$ predicted } \\
\hline$>76$ & 96 & 745 & $546-1051$ & 0.007 \\
\hline$\leq 76$ & 104 & 612 & 428-1076 & \\
\hline \multicolumn{5}{|l|}{ Emphysema } \\
\hline No or mild & 119 & 715 & $532-1174$ & 0.003 \\
\hline Moderate & 56 & 644 & $482-1041$ & \\
\hline Severe & 25 & 465 & $243-644$ & \\
\hline \multicolumn{5}{|l|}{ Chronic cor pulmonale } \\
\hline yes & 47 & 534 & $321-741$ & 0.002 \\
\hline no & 153 & 715 & $529-1164$ & \\
\hline \multicolumn{5}{|c|}{ Systemic arterial hypertension } \\
\hline yes & 95 & 658 & 484-1064 & 0.999 \\
\hline no & 105 & 644 & 477-1076 & \\
\hline \multicolumn{5}{|c|}{ Coronary artery disease } \\
\hline yes & 59 & 681 & $560-1040$ & 0.352 \\
\hline no & 141 & 631 & $465-1087$ & \\
\hline \multicolumn{5}{|l|}{ Heart failure } \\
\hline yes & 23 & 886 & $583-1252$ & 0.376 \\
\hline no & 177 & 641 & $465-1039$ & \\
\hline \multicolumn{5}{|l|}{ Diabetes mellitus } \\
\hline yes & 22 & 920 & $735-1123$ & 0.003 \\
\hline no & 178 & 630 & 475-1069 & \\
\hline \multicolumn{5}{|l|}{ Dyslipidemia } \\
\hline yes & 61 & 681 & 508-1078 & 0.539 \\
\hline no & 139 & 631 & 480-1062 & \\
\hline \multicolumn{5}{|l|}{ Inhaled corticosteroids } \\
\hline yes & 128 & 642 & $482-1076$ & 0.880 \\
\hline no & 72 & 671 & 484-1078 & \\
\hline \multicolumn{5}{|l|}{ Statins } \\
\hline yes & 37 & 681 & 558-1033 & 0.713 \\
\hline no & 163 & 641 & 470-1082 & \\
\hline
\end{tabular}

Definitions of abbreviations: sRAGE = soluble receptor for advanced glycation end products $(\mathrm{pg} / \mathrm{mL}) ; \mathrm{IQr}=$ interquartile range. For the other abbreviations see table 1 . The cutpoints of $\mathrm{FEV}_{1} \%$ predicted are based on GOLD stage (see ref. [1]). The cutpoints for pack-years of smoking and $\mathrm{DL}_{\mathrm{CO}} \%$ predicted are the median value in the whole sample.

It appears, therefore, that emphysema is independently associated with the level of sRAGE in patients with COPD.

In contrast to other tissues, membrane-bound RAGE is highly expressed in the normal adult human lung, especially in the alveolar epithelial cells [31-33]. RAGE is thought to have a homeostatic function in the lung for it enhances the adherence of type I epithelial cells to the extracellular matrix [32], and is implicated in the differentiation of type II into type I epithelial cells, a crucial step in the process of alveolar repair [34].

So, the reduced levels of sRAGE we observed in the patients with moderate to severe emphysema could be the consequence of the extensive disruption of alveoli and alveolar walls that is the hallmark of emphysema.

Alternatively, the reduced levels of sRAGE in emphysemic patients may reflect the exposure to a high burden of RAGE ligands. This could, in turn, be caused by the release of pro-inflammatory cytokines and inflammatory mediators that is known to occur in COPD [35].

We found no significant difference, between cases and controls, in the plasma concentrations of the RAGE ligands CML and S100A12. This is at variance with the results of three recent studies showing that: (a) CML is detected in the epithelial lining fluid from peripheral airways in patients with COPD, and correlates with the severity of airflow obstruction [36]; (b) S100A12 concentration in the sputum of patients with COPD is significantly higher than in healthy subjects [37]; (c) HMGB1 levels in induced sputum are significantly higher in asthmatic patients than in controls, and correlate significantly with the severity of asthma and the percent of neutrophils in sputum [38].

These data suggest compartmentalization of RAGE ligands in the airway lumen in patients with obstructive lung diseases, and may explain why we did not find any significant increase in the circulating levels of CML and S100A12 in our COPD sample.

Since RAGE is considered a marker of alveolar epithelial cell integrity, it may be speculated that disruption of alveolar integrity is associated with downregulation of RAGE. This hypothesis was tested in animal models recapitulating idiopathic pulmonary fibrosis (IPF), and in lung specimens from patients with known IPF $[13,14]$. These studies indicate that: (a) RAGE is downregulated in murine models of IPF; (b) RAGE-null mice are prone to develop fibrotic lesions in their lungs; (c) in humans, RAGE and sRAGE transcripts are significantly reduced in IPF lungs as compared with normal lungs. Taken together these findings support the concept that RAGE may have a protective role in the lungs, and that loss of RAGE contributes to IPF pathogenesis $[13,14]$.

By contrast, immunohistochemical studies show that RAGE is over-expressed in the conducting airways [16] and alveolar walls [39] of patients with COPD. Recently, a proteomic screening study of the lung tissue in patients with IPF and with COPD revealed that full length-RAGE is reduced in both diseases whereas 


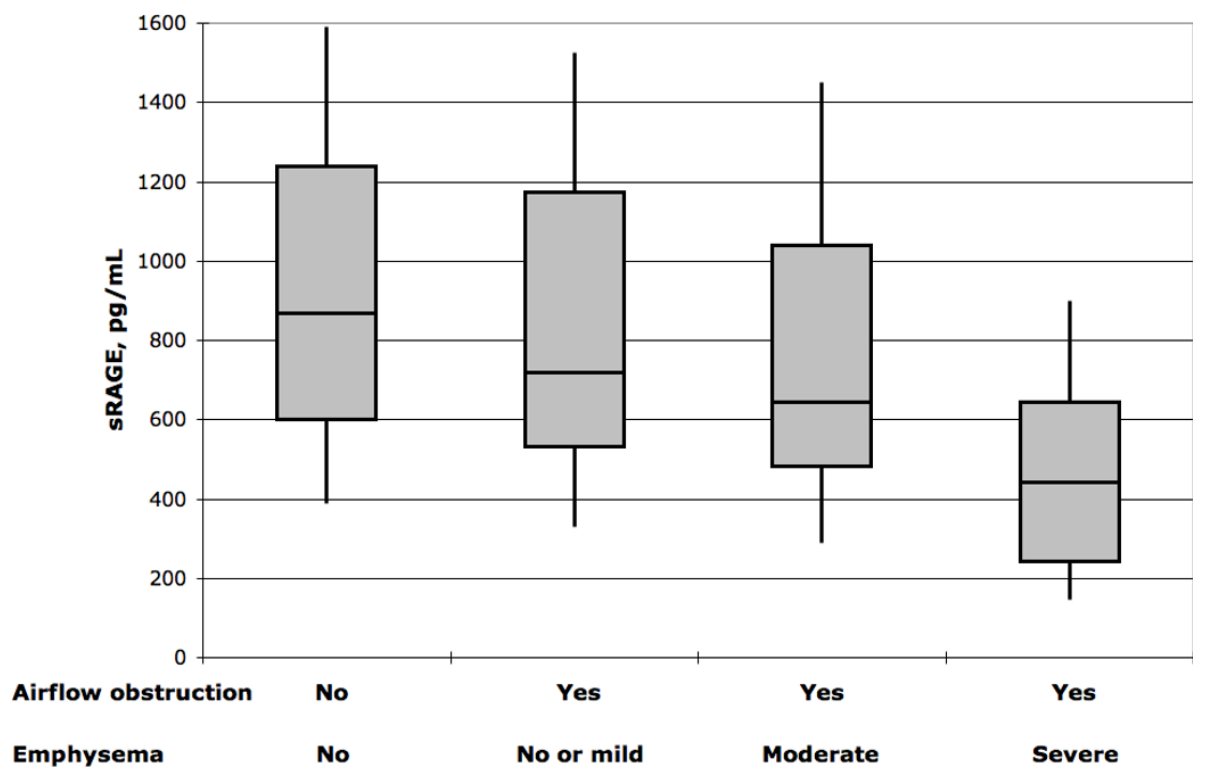

Figure 1 Box-and-whisker plot of the plasma concentration of soluble receptor for advance glycation end products (sRAGE) in the study sample $(\mathbf{n}=\mathbf{4 0 1})$. No airflow obstruction, no emphysema $(n=201)$. Airflow obstruction, no or mild emphysema $(n=119)$. Airflow obstruction, moderate emphysema $(n=56)$. Airflow obstruction, severe emphysema $(n=25)$. Line in box: median. Box height: interquartile range. Whiskers: $10^{\text {th }}$ and $90^{\text {th }}$ percentile. $P<0.001$ by Mood's median test.

Table 4 sRAGE in 201 controls (univariate analysis)

\begin{tabular}{|c|c|c|c|c|}
\hline Characteristics & $\mathrm{n}$ & Median & IQR & P-value \\
\hline \multicolumn{5}{|l|}{ Smoking habits } \\
\hline Current smoker & 101 & 884 & $622-1284$ & 0.888 \\
\hline Former smoker & 100 & 833 & $579-1035$ & \\
\hline \multicolumn{5}{|l|}{ Pack-years of smoking } \\
\hline$>40$ & 101 & 869 & $601-1305$ & 1.000 \\
\hline$\leq 40$ & 100 & 856 & $600-1203$ & \\
\hline \multicolumn{5}{|c|}{ Systemic arterial hypertension } \\
\hline yes & 75 & 790 & $619-1207$ & 0.382 \\
\hline no & 126 & 899 & $591-1248$ & \\
\hline \multicolumn{5}{|c|}{ Coronary artery disease } \\
\hline yes & 55 & 874 & $671-1055$ & 1.000 \\
\hline no & 146 & 855 & $570-1292$ & \\
\hline \multicolumn{5}{|l|}{ Heart failure } \\
\hline yes & 13 & 772 & $663-948$ & 0.568 \\
\hline no & 188 & 876 & $598-1247$ & \\
\hline \multicolumn{5}{|l|}{ Diabetes mellitus } \\
\hline yes & 30 & 907 & $680-1124$ & 0.435 \\
\hline no & 171 & 851 & $584-1247$ & \\
\hline \multicolumn{5}{|l|}{ Dyslipidemia } \\
\hline yes & 74 & 853 & $621-1008$ & 0.884 \\
\hline no & 127 & 874 & 580-1291 & \\
\hline \multicolumn{5}{|l|}{ Statins } \\
\hline yes & 47 & 772 & $617-951$ & 0.182 \\
\hline no & 154 & 899 & $582-1295$ & \\
\hline
\end{tabular}

Definitions of abbreviations: sRAGE = soluble receptor for advanced glycation end products $(\mathrm{pg} / \mathrm{mL}) ; \mathrm{IQr}=$ interquartile range. The cutpoint of 40 pack-years is the median value measured in the whole sample.
esRAGE levels decline in IPF but not in COPD [40]. So, it may be that specific RAGE variants are involved in COPD. This issue warrants further investigation.

Although it was not the primary objective of our study, we found that chronic cor pulmonale is strongly and independently associated with reduced levels of sRAGE in COPD.

Chronic cor pulmonale may develop in COPD as a consequence of anatomic remodeling of the pulmonary vasculature, and sustained vasoconstriction due to chronic hypoxia and superimposed respiratory acidosis [41].

Recent experimental data suggest that reactive oxygen species, released during inflammation, may impact on the structure and function of the right ventricle [42]. So, the low concentrations of sRAGE we measured in the patients with chronic cor pulmonale could again be regarded as indicating exposure to high levels of RAGE ligands. This hypothesis should be further tested in patients with established pulmonary arterial hypertension.

We acknowledge that our study has some limitations. First, given the cross-sectional nature of the study, we obtained a single determination of sRAGE, FEV ${ }_{1}$ and $\mathrm{DL}_{\mathrm{CO}}$, and a single CT scan study. This precluded the possibility of evaluating whether changes in sRAGE over time are predictive of a decline in lung function, or worsening of emphysema in patients with established COPD. Second, we measured total circulating sRAGE because the ELISA method we used does not differentiate 


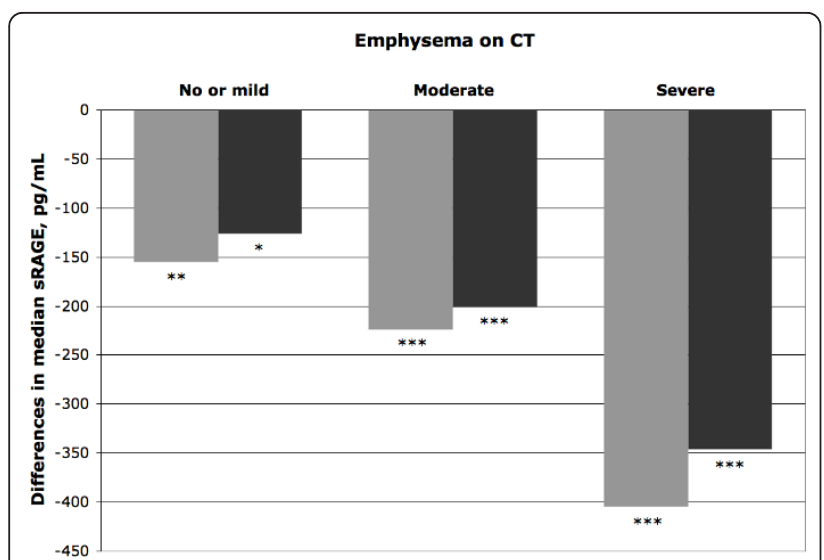

Figure 2 Differences in median sRAGE between COPD patients ( $n=200$ ) and control subjects (no airflow obstruction and no emphysema, $n=201$ ) taken as the referent category. COPD patients are categorized as a function of the presence and severity of emphysema on computed tomography (CT). Grey bars: unadjusted difference. Black bars: difference adjusted for airflow obstruction, pack-years of smoking, coronary artery disease, diabetes, and dyslipidemia. ${ }^{*} p<0.05,{ }^{* *} p<0.01,{ }^{* * *} p<0.001$ against the referent category.

between the shedded isoform and that generated by alternative splicing (esRAGE). Third, we did not measure the expression of RAGE in the lung tissue and, therefore, we could not assess the relationship between the membranebound and the soluble isoforms of the receptor.

Investigating on the dynamics of RAGE and its soluble isoforms in COPD seems warranted in view of the results of two recent meta-analyses of genome-wide, population-based studies [43,44]. A strong association was found between lung function (as reflected by the $\mathrm{FEV}_{1} / \mathrm{FVC}$ ratio) and single nucleotide polymorphisms in the AGER gene encoding RAGE, which is a plausible candidate for causal association $[43,44]$.

\section{Conclusions}

In summary, we found that circulating sRAGE is significantly reduced in COPD patients with respect to ageand sex-matched controls. Emphysema and chronic cor pulmonale are independent predictors of reduced sRAGE levels in COPD.

\section{Acknowledgements}

The authors wish to thank Giosuè Catapano and Cristina Carli for excellent clinical and technical assistance. Permission was obtained from those who are acknowledged.

Funding source: This work was supported by the European Union $5^{\text {th }}$ Framework Programme under the contract number QLG1-CT-2001-01012 (COPD GENE SCAN Project).

\section{Author details}

'Department of Medical and Surgical Critical Care, University of Florence, 50134 Florence, Italy. ${ }^{2}$ Institute of Clinical Physiology, National Research

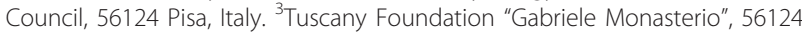

Pisa, Italy. ${ }^{4}$ Unit of Biostatistics, Department of Environmental Medicine, Karolinska Institutet, 70177 Stockholm, Sweden. ${ }^{5}$ Division of Biostatistics, Arnold School of Public Health, University of South Carolina, Columbia, 29208 SC, USA.

\section{Authors' contributions}

MM designed the study; MM, SM, and EF contributed to acquisition and interpretation of data; GB and FC measured SRAGE; MB contributed to statistical analysis; $M M$ and $M B$ drafted the manuscript. All the authors read and approved the final version of the manuscript.

\section{Competing interests}

The authors declare that they have no competing interests.

Received: 7 December 2010 Accepted: 30 March 2011

Published: 30 March 2011

\section{References}

1. Rabe KF, Hurd S, Anzueto A, Barnes PJ, Buist SA, Calverley P, Fukuchi Y, Jenkins C, Rodriguez-Roisin R, van Weel C, Zielinski J: Global Initiative for Chronic Obstructive Lung Disease. Global strategy for the diagnosis, management, and prevention of chronic obstructive pulmonary disease: GOLD executive summary. Am J Respir Crit Care Med 2007, 176:532-555.

2. Agusti AG, Sauleda J, Miralles C, Gomez C, Togores B, Sala E, Batle S, Busquets $X$ : Skeletal muscle apopotosis and wight loss in chronic obstructive pulmonary disease. Am J Respir Crit Care Med 2002, 166:485-489

3. Vestbo J, Prescott E, Almdal T, Dahl M, Nordestgaard BG, Andersen T, Sørensen TIA, Lange P: Body mass, fat-free mass, and prognosis in patients with COPD from a random population sample. Am J Respir Crit Care Med 2006, 173:79-83.

4. Vestbo J, Anderson W, Coxson HO, Crim C, Dawber F, Edwards LD, Hagan G, Knobil K, Lomas DA, MacNee W, Silverman EK, Tal-Singer R, on behalf of the ECLIPSE Investigators: Evaluation of COPD longitudinally to identify predictive surrogate end-points (ECLIPSE). Eur Respir J 2008, 31:869-873.

5. Agusti A, Calverley P, Celli B, Coxson HO, Edwards LD, Lomas D, MacNee W, Miller BE, Rennard S, Silverman EK, Tal-Singer R, Wouters E, Yates JC, Vestbo J: Characterisation of COPD heterogeneity in the ECLIPSE cohort. Respir Res 2010, 11:122.

6. Hurst JR, Vestbo J, Anzueto A, Locantore N, Müllerova H, Tal-Singer R, Miller B, Lomas D, Agusti A, MacNee W, Calverley P, Rennard S, Wouters E, Wedzicha JA, for the ECLIPSE Investigators: Susceptibility to exacerbations in chronic obstructive pulmonary disease. N Engl J Med 2010, 363:1128-1138.

7. Neeper M, Schmidt AM, Brett J, Yan SD, Wang F, Pan YC, Elliston K, Stern D, Shaw A: Cloning and expression of a cell surface receptor for advanced glycosylation end products of proteins. J Biol Chem 1992, 267:14998-15004.

8. Basta G: Receptor for advanced glycation end products and atherosclerosis: from basic mechanisms to clinical implications. Atherosclerosis 2008, 196:9-21.

9. Bierhaus A, Schiekofer S, Schwaninger M, Andrassy M, Humpert PM, Chen J, Hong $M$, Luther T, Henle T, Klöting I, Morcos M, Hofmann M, Tritschler H, Weigle B, Kasper M, Smith M, Perry G, Schmidt AM, Stern DM, Häring HU, Schleicher E, Nawroth PP: Diabetes-associated sustained activation of the transcription factor nuclear factor-kappa B. Diabetes 2001, 50:2792-2808.

10. Park L, Raman KG, Lee KJ, Lu Y, Ferran LJ Jr, Chow WS, Stern D, Schmidt AM: Suppression of accelerated diabetic atherosclerosis by the soluble receptor for advanced glycation end products. Nat Med 1998, 4:1025-1031.

11. Falcone C, Emanuele E, D'Angelo A, Buzzi MP, Belvito C, Cuccia M, Geroldi D: Plasma levels of soluble receptor for advanced glycation end products and coronary artery disease in nondiabetic men. Arterioscler Thromb Vasc Biol 2005, 25:1032-1037.

12. Pullerits $R$, Bokarewa M, Dahlberg L, Tarkowski A: Decreased levels of soluble receptor for advanced glycation end products in patients with rheumatoid arthritis indicating deficient inflammatory control. Arthritis Res Ther 2005, 7:817-824.

13. Englert JM, Hanford LE, Kaminski N, Tobolewski JM, Tan RJ, Fattman CL, Ramsgaard L, Richards TJ, Loutaev I, Nawroth PP, Kasper M, Bierhaus A, 
Oury TD: A role for the receptor for advanced glycation end products in idiopathic pulmonary fibrosis. Am J Pathol 2008, 172:583-591.

14. Queisser MA, Kouri FM, Konigshoff M, Wygrecka M, Schubert U, Eickelberg O, Preissner KT: Loss of sRAGE in pulmonary fibrosis: molecular relations to functional changes in pulmonary cell types. Am J Respir Mol Cell Biol 2008, 39:337-345

15. Smith DJ, Yerkovich ST, Towers MA, Carroll ML, Thomas R, Upham JW: Reduced soluble receptor for advanced glycation end products in chronic obstructive pulmonary disease. Eur Respir J 2010, PMDI:20595148.

16. Ferhani N, Letuve S, Kozhich A, Thibaudeau O, Grandsaigne M, Maret M, Dombret MC, Sims GB, Kolbeck R, Coyle AJ, Aubier M, Pretolani M: Expression of high-mobility group box 1 and of receptor for advanced glycation end products in COPD. Am J Respir Crit Care Med 2010, 181:917-927.

17. Chappell S, Daly L, Morgan K, Baranes TG, Roca J, Rabinovich R, Millar A, Donnelly SC, Keatings V, McNee W, Stolk J, Hiemstra PS, Miniati M, Monti S, O'Connor C, Kalsheker N: Cryptic haplotypes of SERPIN A1 confer susceptibility to chronic obstructive pulmonary disease. Hum Mutat 2006, 27:103-109.

18. Chappell S, Daly L, Morgan K, Guetta-Baranes T, Roca J, Rabinovich R, Millar A, Donnelly SC, Keatings V, McNee W, Stolk J, Hiemstra P, Miniati M, Monti S, O'Connor CM, Kalsheker N: Genetic variants of microsomal epoxide hydrolase and glutamate-cysteine ligase in COPD. Eur Respir J 2008, 32:931-937.

19. Miniati M, Monti S, Stolk J, Mirarchi G, Falaschi F, Rabinovich R, Canapini C, Roca J, Rabe KL: Value of chest radiography in phenotyping chronic obstructive pulmonary disease. Eur Respir J 2008, 31:509-515.

20. Haq I, Chappell S, Johnson SR, Lotya J, Daly L, Morgan K, Guetta-Baranes T, Roca J, Rabinovich R, Millar A, Donnelly SC, Keatings V, McNee W, Stolk J, Hiemstra P, Miniati M, Monti S, O'Connor CM, Kalsheker N: Association of MMP-12 polymorphisms with severe and very severe COPD: a case control study of MMPs 1, 9 and 12 in a European population. BMC Med Genet 2010, 15:11-17.

21. Crapo RO, Morris AH, Gardner RM: Reference spirometric values using equipment and technique that meet ATS recommendations. Am Rev Respir Dis 1981, 123:659-664.

22. Miller MR, Hankinson J, Brusasco V, Burgos F, Casaburi R, Coates A, Crapo R, Enright P, van der Grinten CP, Gustafsson P, Jensen R, Johnson DC, Macintyre N, McKay R, Navajas D, Pedersen OF, Pellegrino R, Viegi G, Wanger J, ATS/ERS Task Force: Standardisation of spirometry. Eur Respir $J$ 2005, 26:319-338.

23. Macintyre N, Crapo RO, Viegi G, Johnson DC, van der Grinten CP, Brusasco V, Burgos F, Casaburi R, Coates A, Enright P, Gustafsson P, Hankinson J, Jensen R, McKay R, Miller MR, Navajas D, Pedersen OF, Pellegrino R, Wanger J: Standardisation of the single-breath determination of carbon monoxide uptake in the lung. Eur Respir J 2005, 26:720-735

24. Jurcut R, Giusca S, La Gerche A, Vasile S, Ginghina C, Voigt J-U: The echocardiographic assessment of the right ventricle: what to do in 2010? Eur J Echocardiogr 2010, 11:81-96.

25. Jones PW, Quirk FH, Baveystock CM, Littlejohn P: A self-complete measure of heath status for chronic airflow limitation. The St. George's respiratory questionnaire. Am Rev Respir Dis 1992, 145:1321-1327.

26. Basta G, Sironi AM, Lazzerini G, Del Turco S, Buzzigoli E, Casolaro A, Natali A, Ferrannini $E$, Gastaldelli A: Circulating soluble receptor for advanced glycation end products is inversely associated with glycemic control and S100A12 protein. J Clin Endocrinol Metab 2006, 91:4628-4634.

27. Anderson MM, Raquena JR, Crowley JR, Thorpe SR, Heinecke JW: The myeloperoxidase system of human phagocytes generates $\mathrm{N}$-epsiloncarboxymethyl lysine on proteins: a mechanism for producing advanced glycation end products at sites of inflammation. J Clin Invest 1999, 104:103-113.

28. Vogl T, Pröpper C, Hartmann M, Strey A, Strupat K, van den Bos C, Sorg C, Roth J: S100A12 is expressed exclusively by granulocytes and acts independently from MRP8 and MRP14. J Biol Chem 1999, 274:25291-25296.

29. Beigelman-Aubry C, Hill C, Guibal A, Savatovsky J, Grenier PA: Multidetector row $\mathrm{CT}$ and postprocessing techniques in the assessment of diffuse lung disease. Radiographics 2005, 25:1639-1652.
30. Thurlbeck WM, Dunnill MS, Hartung W, Heard BE, Heppleston AG, Ryder RC: A comparison of three methods of measuring emphysema. Hum Pathol 1970, 1:215-226.

31. Brett J, Schmidt AM, Yan SD, Zou YS, Weidman E, Pinsky D, Nowygrod R, Neeper M, Przysiecki C, Shaw A, Migheli A, Stern D: Survey of the distribution of a newly characterized receptor for advanced glycation end products in tissues. Am J Pathol 1993, 143:1699-1712.

32. Fehrenbach $H$, Kasper M, Tschernig T, Shearman MS, Schuh D, Müller M: Receptor for advanced glycation end products (RAGE) exhibits highly differential cellular and subcellular localization in rat and human lung. Cell Mol Biol 1998, 44:1147-1157.

33. Morbini P, Villa C, Campo I, Zorzetto M, Inghilleri S, Luisetti M: The receptor for advanced glycation end products and its ligands: a new inflammatory pathway in lung disease? Mod Pathol 2006, 19:1437-1445.

34. Demling N, Ehrhardt C, Kasper M, Laue M, Knels L, Rieber EP: Promotion of cell adherence and spreading: a novel function of RAGE, the highly selective differentiation marker of human alveolar epithelial type I cells. Cell Tissue Res 2006, 323:475-488.

35. Cosio M, Saetta M, Agusti A: Immunologic aspects of chronic obstructive pulmonary disease. N Engl J Med 2009, 360:2445-2554.

36. Kanazawa H, Kodama T, Asai K, Matsumura S, Hirata K: Increased levels of $\mathrm{N}$ (epsilon)-(carboxymethyl)lysine in epithelial lining fluid from peripheral airways in patients with chronic obstructive pulmonary disease: a pilot study. Clin Sci (Lond) 2010, 119:143-149.

37. Lorenz E, Muhlebach MS, Tessier PA, Alexis NE, Duncan Hite R, Seeds MC, Peden DB, Meredith W: Different expression ratio of S100A8/A9 and S100A12 in acute and chronic lung diseases. Respir Med 2008, 102:567-573

38. Watanabe $T$, Asai K, Fujimoto $H$, Tanaka H, Kanazawa H, Hirata K: Increased levels of HMGB-1 and endogenous secretory RAGE in induced sputum from asthmatic patients. Respir Med 2010.

39. Wu L, Ma L, Nicholson L, Black PN: Advanced glycation end products and its receptor (RAGE) are increased in patients with COPD. Respir Med 2011, 105:329-336.

40. Ohlmeier S, Mazur W, Salmenkivi K, Myllarniemi M, Bergmann U, Kinnula VL: Proteomic studies on receptor for advanced glycation end product variants in idiopathic pulmonary fibrosis and chronic obstructive pulmonary disease. Proteomics Clin Appl 2010, 4:97-105.

41. Enson Y, Giuntini C, Lewis ML, Morris TQ, Harvey RM: The influence of hydrogen ion and hypoxia on the pulmonary circulation. $J$ Clin Invest 1964, 43:1146-1162.

42. Bogaard HJ, Abe K, Noordergraaf AV, Voelkel NF: The right ventricle under pressure: cellular and molecular mechanisms of right-heart failure in pulmonary hypertension. Chest 2009, 135:794-804.

43. Repapi E, Sayers I, Wain LV, Burton PR, Johnson T, Obeidat M, Zhao JH, Ramasamy A, Zhai G, Vitart V, Huffman JE, Igl W, Albrecht E, Deloukas P, Henderson J, Granell R, McArdle WL, Rudnicka AR, Barroso I, Loos RJ, Wareham NJ, Mustelin L, Rantanen T, Surakka I, Imboden M, Wichmann HE, Grkovic I, Jankovic S, Zgaga L, Hartikainen A, et al: Meta-analyses of genome-wide association studies identify five loci associated with lung function. Nat Med 2010, 42:36-44.

44. Hancock DB, Eijgelsheim M, Wilk JB, Gharib SA, Loehr LR, Marciante KD, Franceschini N, van Durme YM, Chen TH, Barr RG, Schabath MB, Couper DJ, Brusselle GG, Psaty BM, van Duijn CM, Rotter Jl, Uitterlinden AG, Hofman A, Punjabi NM, Rivadeneira F, Morrison AC, Enright PL, North KE, Heckbert SR, Lumley T, Stricker BH, O'Connor GT, London SJ: Meta-analyses of genomewide association studies identify multiple loci associated with lung function. Nat Med 2010, 42:45-52.

doi:10.1186/1465-9921-12-37

Cite this article as: Miniati et al: Soluble receptor for advanced glycation end products in COPD: relationship with emphysema and chronic cor pulmonale: a case-control study. Respiratory Research 2011 12:37. 